\title{
PENGARUH KUALITAS KEHIDUPAN KERJA TERHADAP KEPUASAN KERJA KARYAWAN RUMAH SAKIT IBU DAN ANAK X SURABAYA
}

\author{
The Influence of Quality of Work Life toward Job Satisfaction of Employees in \\ Maternal and Child Hospital $X$ Surabaya \\ Rinanti Rahayuning Bekti \\ PERSAKMI Jawa Timur, Indonesia \\ E-mail:rinanti.rahayuning.bekti-2014@fkm.unair.ac.id
}

\begin{abstract}
Background: The turnover rate in RSIA X Surabaya increased during the last two months from January to February 2018. Turnover rate in January 2018 was 1.56\% and in February 2018 was 2.38\%. The increased turn over rate in RSIA X Surabaya was probably due to poor quality of work life that can be influenced to performance satisfaction and causing employee resign from their job.

Aim: This research aimed to analyze the influence of quality of work life toward employee job satisfaction in RSIA $X$ Surabaya.

Method: It was an analytical study by cross sectional design. The samples were 57 respondents chosen by simple random sampling.

Results: The result of this research showed that quality of work life had an influence toward employee job satisfaction in RSIA X Surabaya with significance value equal to 0.024 or $<\alpha=0.05$. It showed that employee job satisfaction increases along with the better quality of work life.

Conclusion: In conclusion, there was an influence of quality of work life towards employee satisfaction. The hospital should take more attention to the quality of work life for employees in the future so that employees still continue working in the organization.
\end{abstract}

Keywords: employee, job satisfaction, quality of work life

\begin{abstract}
ABSTRAK
Latar Belakang:Angkaturnover karyawan di RSIA X Surabaya meningkat selama dua bulan terakhir yaitu bulan Januari hingga Februari 2018. Angka turnover pada bulan Januari sebesar $1,56 \%$ dan bulan Februari sebesar $2,38 \%$. Meningkatnya angkaturnover di RSIA X Surabaya bisa disebabkan karena quality of work lifeyang kurang baik sehingga berdampak terhadap kepuasan kinerja dan menyebabkan karyawan mengundurkan diri dari pekerjaannya.

Tujuan:Penelitian ini bertujuan menganalisis pengaruh quality of work lifeterhadap kepuasan kerja karyawan di RSIA X Surabaya. Jeneis penelitian analitik dengan desain penelitian adalah cross sectional. Besar sampel sebesar 57 responden dihitung menggunakan simple random sampling.

Hasil:Hasil regresi linier menunjukkan bahwa quality of work lifeberpengaruh terhadap kepuasan kerja karyawan di RSIA X Surabaya dengan nilai signifikansi sebesar 0,024 atau $<\alpha=0,05$. Hal tersebut menunjukkan bahwa peningkatan quality of work lifeseiring dengan kepuasan kerja karyawan.

Kesimpulan: Dapat disimpulkan bahwa ada pengaruh kualitas kehidupan kerja terhadap kepuasan pegawai. Oleh sebab itu pihak rumah sakit diharapkan lebih memperhatikan quality of work lifekaryawanagar kedepannya karyawan dapat bertahan dalam organisasi tersebut.
\end{abstract}

Kata Kunci:karyawan, kepuasan kerja, kualitas kehidupan kerja

\section{PENDAHULUAN}

Era globalisasi seperti saat ini menuntut fasilitas pelayanan kesehatan seperti rumah sakit, ibu dan anak untuk bersaing dalam memberikan pelayanan kesehatan paripurna dan bermutu bagi bagi ibu dan anak. Tentunya hal tersebut juga dipengaruhi oleh peran dan fungsi sumber daya manusia yang dimiliki oleh sebuah rumah sakit.
Salah satu aspek penting dalam menciptakan pelayanan kesehatan yang bermutu adalah dengan meningkatkan kualitas sumber daya manusia yang dimiliki oleh sebuah rumah sakit.

Hal tersebut dikarenakan sumber daya manusia yang dimiliki oleh sebuah organisasiadalahharta berharga yang harus dijaga kualitasnya agar mampu memberikan pelayanan yang bermutu bagi masyarakat. Kondisi yang 
dibutuhkan dalam memberikan pelayanan kesehatan yang bermutu bukan hanya dari kompetensi yang dimiliki oleh karyawan, namun ada yang lebih penting yaitu suasana kerja yang kondusif dan memiliki daya saing dengan rumah sakit lain. Cara yang dapat dilakukan oleh sebuah rumah sakit untuk mempertahankan karyawannya adalah dengan memelihara kualitas kehidupan kerja (quality of work life) agar tercipta kepuasan kerja karyawan.

Berdasarkan data yang diperoleh dari pihak manajemen RSIA X Surabaya dapat diketahui bahwaturnover rate karyawan RSIA X Surabaya pada bulan Januari 2018 sebesar 1,56\%, sedangkan pada bulan Februari 2018 angka turnover rate meningkat menjadi $2,38 \%$. Nilai turnover rate yang semakin meningkat akan menyebabkan kerugian bagi pihak RSIA $X$ Surabaya. Meningkatnya turnover rate di RSIA X Surabaya mungkin disebabkan karena kondisi lingkungan kerja (quality of work life) yang kurang baik sehingga berdampak terhadap kepuasan kinerja dan menyebabkan karyawan mengundurkan diri dari pekerjaannya.

Terdapat dua cara yang digunakan untuk mengetahui arti kualitas hidup kerja (quality of work life). Pertama, kualitas kehidupan kerja memiliki hubungan yangberbanding lurus denganusaha organisasi untuk mewujudkan tujuan yang ditetapkan sebelumnya.Kedua, kualitas kehidupan kerja merupakan persepsi yang dimiliki oleh karyawan mengenai keinginan untuk memperoleh rasa aman, kepuasan terhadap pekerjaan, serta mampu tumbuh dan berkembang.

Berdasarkan uraian diatas maka dapat disimpulkan bahwa kualitas kehidupan kerja (quality of work life) merupakan persepsi karyawan mengenai kondisi kesejahteraan baik fisik maupun mental saat bekerja(Cascio,2015).Menciptakan kualitas kehidupan kerja (quality of work life) yang baik memiliki tujuan untuk mewujudkan iklim kerja yang dapat mendorong karyawan untuk meningkatkan motivasi dalam bekerja agar mencapai kinerja yang optimal serta bertujuan untuk memenuhi kebutuhan karyawan dengan menyediakan sarana dan prasarana di lingkungan kerja.

Sedangkan kepuasan kerja merupakan gambaran perasaan atau sikap seorang karyawan dalam bentuk rasa senang atau tidak senang, maupun puas atau tidak puas terhadap pekerjaan yang dilakukan(Rivai, 2014). Kepuasan kerja yang dirasakan oleh tiap karyawan memiliki tingkatan yang berbeda.Apabila seorang karyawan memiliki tingkat kepuasan kerja yang tinggi, maka karyawan tersebut merasa semakin nyaman dengan lingkungan kerjanya. Adapun faktor yang berkaitan dengan kepuasan kerja antara lain sudut pandang tentang bekerja, pandangan tentang makna kepuasan, karakteristik individu, jenis pekerjaan, serta lingkungan kerja.Kualitas kehidupan kerja (quality of work life)sangat penting untuk diperhatikan, hal tersebut mengingat bahwa karyawan adalah aset yang berharga bagi sebuah organisasi.
Apabila sebuah organisasi mampu memberikan kualitas kehidupan kerja yang baik, maka hal tersebut akan memiliki dampak terhadap kepuasan kerja karyawan yang akan berakhir pada kinerja karyawan yang semakin baik. Penelitian ini memiliki tujuan untuk menganalisis pengaruh kualitas kehidupan kerja(quality of work life) terhadap kepuasan kerja karyawan di RSIA X Surabaya.Hasil dari penelitian ini diharapkan dapat menjadi masukan perbaikan bagi manajemen RSIA $X$ Surabaya untuk meningkatkan kepuasan kerja karyawan melalui peningkatan kualitas kehidupan kerja karyawan (quality of work life).

\section{METODE}

Metode yang digunakan dalam penelitian ini adalah penelitian analitik. Rancang bangun penelitian cross sectional.Lokasi penelitian adalah di Rumah Sakit lbu dan Anak X Surabaya. Waktu pelaksanaan penelitian dilaksanakan pada bulan Februari 2018. Populasi dalam penelitian ini adalah seluruh karyawan yang bekerja di Rumah Sakit lbu dan Anak $X$ Surabaya.Besar sampel penelitian dihitung dengan menggunakan metode simple random sampling dari Lemeshow.Hasil penghitungan didapatkan sebanyak 57 responden.Penentuan besar sampel pada tiap unit kerja didapatkan dengan perhitungan menggunakan metode proportional random sampling.

Pengambilan data primer dengan membagikan kuesioner kepada responden. Kuesioner yang dibagikan meliputi kepuasan kerja karyawan, dan kualitas kehidupan kerja (quality of work life. Kepuasan kerja karyawan diukur dengan kuesioner yang terdiri dari 20 pertanyaan. Kuesioner kepuasan kerja karyawan bertujuan untuk mengukur kepuasan kerja baik intrinsik (12 pertanyaan) dan kepuasan kerja ekstrinsik (8 pertanyaan).

Pengukuran kualitas kehidupan kerja (quality of work life) dilakukan menggunakan kuesioner yang terdiri dari 18 pertanyaan (Cascio, 2015) kemudian dimodifikasi dengan penelitian sebelumnya. Indikator kualitas kehidupan kerja (quality of work life) terdiri dari 9 indikator yang meliputi keterlibatan karyawan (employee participation), kompensasi yang seimbang (equitable compensation), rasa bangga terhadap instansi (pride), rasa aman terhadap pekerjaan (job security), keselamatan lingkungan kerja (save environment), kesejahteraan (wellness), pengembangan karir (career development), penyelesaian masalah (conflict resolution), dan komunikasi (communication) (Cascio, 2015).

Teknik analisis data pada penelitian ini menggunakan aplikasi SPSS Statistics 21 dengan menghitung skor kepuasan kerja karyawan dan kualitas kehidupan kerja (quality of work life). Hasil penghitungan skor kepuasan kerja karyawan kemudian dikategorikan menjadi tiga yaitu rendah (20-40), dan sedang (41-60), dan tinggi (61-80). Hasil skor kualitas kehidupan kerja (quality of work life) kemudiandikategorikan menjadi tiga yaitu kurang (18-36), cukup (37-54), dan baik (55-72). Selanjutnya untuk menguji pengaruh kualitas 
kehidupan kerja (quality of work life) terhadap kepuasan kerja karyawan, maka dilakukan uji statistik dengan menggunakan regresi linier sederhana.

\section{HASIL DAN PEMBAHASAN}

\section{Kualitas Kehidupan Kerja (Quality of Work Life)}

Kualitas kehidupan kerja (quality of work life) pertama kali dipopulerkan pada tahun 1972 saat Konferensi Buruh Internasional. Kualitas kehidupan kerja (quality of work life) mendapatkan perhatian dan dimaksudkan untuk mengubah sistem kerja agar kepuasan kerja karyawan dapat meningkat. Kualitas kehidupan kerja (quality of work life) adalah proses yang dilakukan oleh sebuah organisasi dalam menjamin kesejahteraan karyawan keamanan kerja, kepuasan kerja, sistem penghargaan yang baik, keuntungan karyawan, keterlibatan karyawan dalam mencapai tujuan yang telah ditetapkan oleh sebuah organisasi (Robbins and Judge, 2013). Peran organisasi dalam mewujudkan kualitas kehidupan kerja (quality of work life) yang baikmerupakan usaha yang dilakukan untuk memenuhi kebutuhan kesejahteraan karyawan baik secara fisik maupun psikis.

Quality of Work Life atau yang biasa disebut dengan kualitas kehidupan kerjaterbagi menjadi 9 indikator yaitu keterlibatan karyawan (employee participation), kompensasi yang seimbang (equitable compensation), rasa bangga terhadap instansi (pride), rasa aman terhadap pekerjaan (job security), keselamatan lingkungan kerja (save environment), kesejahteraan (wellness), pengembangan karir (career development), penyelesaian masalah (conflict resolution), dan komunikasi (communication) (Cascio, 2015).

Keterlibatan kerja karyawan (employee participation) didefinisikan sebagai cara pandang yang digunakan untuk melihat karyawan apakah diikutkan dalam menentukan keputusan atas pekerjaan yang dimiliki. Seorang karyawan memiliki hak dalam pengambilan keputusan baik yang mempengaruhi secara langsung ataupun tidak langsung terhadap pekerjaan, hal tersebut dikarenakan kualitas kehidupan kerja tidak dapat diputuskan secara sepihak oleh pihak organisasi, namun harus melalui kesepakatan antara atasan dan bawahan. Partisipasi karyawan dapat diukur melalui kerjasama antar karyawan, partisipasi karyawan dalam rapat, dan peningkatan kualitas tim (Cascio, 2015).

Kompensasi yang seimbang (equitable compensation) merupakan sistem imbalan yang diberikan kepada karyawannya sebagai bentuk balas jasa atas kinerja dan pengabdian yang dilakukan terhadap pekerjaan. Pemberian kompensasi adalah upaya organisasi untuk meningkatkan motivasi dan prestasi kerja karyawan. Kompensasi yang diberikan oleh organisasi kepada karyawan harus disesuaikan dengan sistem penggajian yang berlaku di pasaran kerja. Apabila sebuah organisasi mampu memberikan kompensasi yang seimbang, layak, dan mampu memenuhi kebutuhan baik materiil maupun non materiil karyawan, maka akan berdampak kepada kepuasan kerja (Wursanto, 2010)

Rasa bangga terhadap instansi (pride) merupakan rasa "memiliki" yang timbul dari dalam diri karyawan terhadap organisasi tempat ia bekerja. Karyawan yang memiliki rasa bangga terhadap pekerjaan dan tempat kerja maka akan menunjukkan kinerja yang optimal demi kemajuan organisasi. Kebanggan karyawan terhadap organisasi tempat kerja dipengaruhi oleh partisipasi perusahaan dalam bidang kemasyarakatan, identitas yang dimiliki oleh perusahaan, dan kepedulian yang dilakukan oleh perusahaan terhadap lingkungan (Cascio, 2015).

Rasa aman terhadap pekerjaan (job security) diwujudkan dalam bentuk status kepegawaian yang dimiliki. Kesepakatan antara organisasi dengan karyawan sangat penting untuk diperhatikan hal tersebut bertujuan agar karyawan merasa aman karena ia yakin bahwa organisasi tempat kerja tidak akan melakukan pemecatan secara sepihak. Bentuk upaya yang dapat dilakukan oleh organisasi kepada karyawan agar karyawan memiliki rasa aman terhadap pekerjaan antara lain jaminan bahwa tidak akan dilakukan pemberhentian pegawai tetap, dan tersedianya program pensiun bagi karyawan yang telah mengabdi kepada perusahaan (Cascio, 2015).

Keselamatan lingkungan kerja (save environment) dapat berwujud lingkungan kerja yang nyaman dan aman sehingga dapat memudahkan karyawan dalam menjalankan aktivitivas agar terwujud produktifitas kerja. Jaminan keselamatan lingkungan kerja yang dapat dilakukan melalui pembentukan komite keselamatan, tim penolong gawat darurat, serta program jaminan keselamatan kerja (Cascio, 2015).

Kesejahteraan (wellness) merupakan upaya yang dilakukan oleh organisasi untuk mempertahankan karyawannya yang diwujudkan dalam bentuk ketersediaan fasilitas yang memadai. $\mathrm{Hal}$ tersebut bertujuan untuk memuaskan kebutuhan karyawan dalam bekerja, sehingga tercipta disiplin kerja, loyalitas, dan dedikasi penuh yang diberikan karyawan kepada suatu organisasi.

Pengembangan karir (career development) dapat diartikan sebagai upaya organisasi untuk meningkatkan dan mengembangkan kemampuan karyawan baik pengetahuan, keterampilan, sikap, ataupun perilaku karyawan dalam melaksanakan pekerjaannya. Pengembangan karir memiliki tujuan untuk menyelaraskan antara kemampuan dan kualifikasi yang dimiliki oleh karyawan. Pengelolaan dan pengembangan karir diperlukan untuk menciptakan produktivitas kerja (Robbins and Judge, 2013).

Penyelesaian masalah (conflict resolution) merupakan upaya yang dilakukan organisasi untuk membantu karyawan dalam mengatasi permasalahan yang dihadapi oleh karyawan tentang pekerjaan yang dimilikinya. Beberapa hal yang dilakukan untuk membantu memecahkan masalah yang dihadapi karyawan adalah keterbukaan, proses penyampaian keluaran secara formal, dan pertukaran pendapat (Cascio, 2015). 
Komunikasi (communication) merupakan sarana bagi karyawan untuk membagikan informasi baik dari dalam maupun ke luar organisasi untuk proses pengendalian manajemen, serta membantu karyawan untuk memecahkan masalah, serta pengambilan keputusan. Komunikasi dalam organisasi dapat dilaksanakan melalui pertemuan tatap muka, pertemuan kelompok,dan publikasi (Cascio, 2015)

Penerapan kualitas kehidupan kerja (quality of work life) diharapkan dapat mewujudkan kehidupan kerja yang berkualitas sehingga karyawan dapat meningkatkan produktivitas kerja, dan mencapai kepuasan terhadap lingkungan kerjanya. Penerapan kualitas kehidupan kerja (quality of work life) yang baik membutuhkan beberapa syarat yang harus dipenuhi antara lain manajer harus menjadi pemimpin yang baik dan dapat menjadi pembimbing bagi karyawannya, keterbukaan dan kepercayaan yang tercipta antara manajer dengan karyawan, memberikan kesempatan bagi karyawan untuk menyampaikan pendapat dan guna perbaikan manajemen, harus menerapkan kualitas kehidupan kerja (quality of work life) secara berkelanjutan mulai dari pemecahan hingga pembentukan mitra kerja antara manajer dengan karyawan, dan menerapkan kualitas kehidupan kerja (quality of work life) dibutuhkan sebuah komitmen yang baik antara pihak manajemen dengan seluruh karyawan (Cascio, 2015).

\section{Kepuasan Kerja}

Kepuasan kerja karyawan ialah sikap yang ditunjukkan oleh karyawan terhadap pekerjaan yang dilakukannya (Robbins and Judge, 2013). Karyawan dengan kepuasan kerja yang tinggi, maka cenderung menunjukkan sikap yang positif terhadap pekerjaannya, sedangkan karyawan yang tidak puas terhadap pekerjaannya cenderung menunjukkan sikap yang negatif. Jadi dapat disimpulkan bahwa kepuasan kerja adalah perasaan yang timbul dari dalam diri seorang karyawan terhadap.

Karyawan yang memiliki kepuasan terhadap pekerjaannya akan mampu berinteraksi dengan lingkungan kerjanya secara baik dan mampu bekerja dengan penuh rasa sungguh-sungguh dan semangat kerja yang tinggi untuk mencapai tujuan dari sebuah organisasi. Pengukuran kepuasan kerja karyawan dapat dilakukan dengan mengidentifikasi beberapa faktor yang terdiri dari konten dari sebuah pekerjaan, penampilan dari tugas pekerjaan yang aktual, pengawasan yang dilakukan oleh atasan, organisasi dan manajemen, kesempatan untuk maju, penggajian, insentif, rekan kerja, dan kondisi lingkungan dari pekerjaan itu sendiri (Rivai, 2014).

Kepuasan kerja adalah komponen penting dalam kepuasan hidup yang dimiliki oleh seorang karyawan, sehingga sangat penting untuk diperhatikan sebagai upaya yang dilakukan oleh organisasi dalam pengembangan dan pemeliharaan karyawan. Apabila seorang karyawan tidak mendapatkan rasa puas dalam bekerja maka dapat mempengaruhi motivasi dan kedisiplinan dalam menjalankan pekerjaannya. Motivasi dan kedisiplinan yang semakin menurun dapat berdampak kepada tingginya tingkat absensi yang berujung pada keinginan karyawan untuk keluar dari sebuah organisasi. Hal tersebut menunjukkan bahwa kepuasan kerja seorang karyawan menjadi faktor yang menentukkan kelangsungan operasional sebuah organisasi.

Pada penelitian ini, kepuasan kerja diukur dengan menggunakan The Minnesota Satisfaction Questionnaire (MSQ), yang merupakan suatu instrumen atau alat untuk mengukur kepuasan kerja yang didalamnya memuat secara rinci mengenai unsur-unsur yang dilakukan untuk mengukur kepuasan kerja seorang karyawan. Pengukuran kepuasan kerja dengan instrumen MSQ terbagi menjadi dua yaitu kepuasan kerja intrinsik dan kepuasan kerja ekstrinsik. Instrumen kepuasan kerja MSQ terdiri dari 20 pertanyaan yang meliputi 12 pertanyaan untuk kepuasan kerja instrinsik, 6 pertanyaan kepuasan kerja ekstrinsik, serta 2 pertanyaan untuk kepuasan kerja secara umum.

\section{Gambaran Umum Karakteristik Responden}

Berdasarkan data yang diperoleh, hasil penelitian menunjukkan bahwa mayoritas responden yang merupakan karyawan RSIA X Surabaya berjenis kelamin perempuan yaitu sebanyak 38 orang $(66,67 \%)$. Hasil tabulasi silang antara jenis kelamin responden dengan kepuasan kerja pada penelitiani ini didapatkan hasil bahwa 9 karyawan perempuan memiliki tingkat kepuasan kerja yang tinggi, sedangkan karyawan laki-laki yang memiliki tingkat kepuasan kerja tinggi hanya sebanyak 8 orang. Hal tersebut sejalan dengan hasil penelitian yang dilakukan oleh (Suryaratri and Rizanati, 2017) menunjukkan bahwa adanya perbedaan kepuasan kerja perawat ditinjau dari jenis kelamin, karyawan perempuan memiliki kepuasan kerja lebih tinggi dibandingkan dengan perawat laki-laki.

Hasil penelitian didapatkan bahwa mayoritas responden yang merupakan karyawan RSIA X Surabaya berusia 21-30 tahun yaitu sebanyak 39 orang $(68,42 \%)$. Hasil tabulasi silang antara usia dengan kepuasan kerja menunjukkan bahwa sebanyak 12 karyawan yang memiliki tingkat kepuasan kerja dengan kategori tinggi berada pada rentang usia 21-30 tahun, sedangkan untuk karyawan yang berusia 31-40 tahun hanya sebanyak 2 orang yang memiliki tingkat kepuasan kerja pada kategori tinggi. Karyawan usia 41-50 tahun yang memiliki kepuasan kerja pada kategori tinggi sebanyak 1 orang, dan karyawan usia 51-60 tahun yang memiliki kepuasan kerja pada kategori tinggi sebanyak 2 orang.

Hal tersebut menunjukkan bahwa kepuasan kerja karyawan cenderung mengalami penurunan seiring dengan bertambahnya usia. Penelitian yang dilakukan oleh (Zein, Setyaningrum and Marlinae, 2016) didapatkan hasil bahwa terdapat pengaruh usia terhadap kepuasan kerja. Hal ini sejalan dengan hasil penelitian yang dilakukan oleh (Budi Santoso, 2014) yang menyebutkan bahwa ada hubungan yang kuat antara usia dengan kepuasan kerja. Hal tersebut dilihat dari kecenderungannya dimana semakin tua usia karyawan akan semakin 
tinggi pula kepuasan atas pekerjaannya. Kepuasan kerja erat kaitannya dengan motivasi karyawan. Tingginya motivasi seorang karyawan akan berdampak terhadap kepuasan kerja.

Hasil penelitian berdasarkan pendidikan akhir responden diketahui bahwa mayoritas responden yang merupakan karyawan RSIA $X$ Surabaya memiliki pendidikan akhir diploma yaitu sebanyak 23 orang (40,35\%). Hasil tabulasi silang antara tingkat pendidikan dengan kepuasan kerja menunjukkan bahwa karyawan dengan tingkat kepuasan kerja pada kategori tinggi paling banyak berada pada karyawan yang memiliki pendidikan akhir $\mathrm{S} 1$ yaitu sebanyak 9 orang, kemudian disusul dengan tingkat pendidikan akhir diploma sebanyak 4 orang, dan tingkat pendidikan akhir SMA/sederajat sebanyak 4 orang. Hal tersebut menunjukkan bahwa semakin tinggi tingkat pendidikan karyawan cenderung memiliki kepuasan kerja yang tinggi pula.

Seorang karyawan dengan latar belakang pendidikan yang rendah memiliki kecenderungan mudah mengalami stress jika dibandingkan dengan karyawan yang memiliki tingkat pendidikan yang tinggi. Hal tersebut dikarenakan seorang yang memiliki tingkat pendidikan yang tinggi lebih memiliki pandangan yang realistis apabila menjumpai kesenjangan antara harapan dan kenyataan yang dimilikinya, sedangkan seseorang dengan pendidikan yang rendah maka akan lebih mudah gelisah dan kecewa apabila sering dihadapkan dengan kesenjangan antara harapan dan kenyataan.

Tingkat pendidikan seorang karyawan juga memiliki hubungan dengan kecerdasan seorang karyawan. Tingkat intelegensi yang terlalu rendah ataupun sebaliknya dapat menyebabkan seorang karyawan mengalami kebosanan sehingga berdampak pada ketidakpuasan kerja. Oleh sebab itu kualifikasi pendidikan seorang karyawan penting untuk diperhatikan agar menghasilkan kepuasan kerja dan berdampak terhadap kinerjanya.

Hasil distribusi frekuensi berdasarkan lama kerja karyawan dapat diketahui bahwa mayoritas responden memiliki masa kerja 37-48 bulan yaitu sebanyak 24 orang $(42,11 \%)$. Hasil tabulasi silang antara masa kerja dengan kepuasan kerja menunjukkan bahwa karyawan yang memiliki masa kerja 37-48 bulan memiliki tingkat kepuasan kerja pada kategori tinggi jika dibandingkan dengan karyawan yang mempunyai masa kerja $\leq 37$ bulan.

$\mathrm{Hal}$ tersebut menunjukkan bahwa masa kerja memiliki pengaruh terhadap kepuasan kerja. Hal tersebut sejalan dengan penelitia yang dilakukan oleh (Haedar, Saharuddin and $H, 2015$ ) yang menyebutkan bahwa terdapat pengaruh antara masa kerja terhadap kepuasan kerja. Hasil penelitian tersebut juga sejalan dengan penelitian yang dilakukan oleh (Sholeha, Kristanti and Jokom, 2015)yang menyebutkan bahwa karyawan dengan masa kerja lebih lama memiliki kecenderungan kepuasan kerja yang lebih tinggi dibandingkan dengan karyawan yang memiliki masa kerja yang baru, dengan kata lain kepuasan kerja akan meningkat seiring dengan lamanya masa kerja seorang karyawan.

\section{Gambaran Quality of Work Life di RSIA X Surabaya \\ Kualitas kehidupan kerja (quality of work} life)yang baik dapat diukur melalui 9 indikator yang terdiri dari dari keterlibatan karyawan (employee participation), kompensasi yang seimbang (equitable compensation), rasa bangga terhadap instansi (pride), rasa aman terhadap pekerjaan (job security), keselamatan lingkungan kerja (save environment), kesejahteraan (wellness), pengembangan karir (career development), penyelesaian masalah (conflict resolution), komunikasi (communication).

Indikator pertama yaitu keterlibatan karyawan (employee participation). Keterlibatan karyawan merupakan sejauh mana pihak rumah sakit melibatkan seorang karyawan dalam menentukan keputusan atas pekerjaan yang dimilikinya. Berdasarkan hasil penelitian dapat dilihat sebanyak 38 responden $(66,7 \%)$ menyatakan bahwa atasan selalu mengikutsertakan karyawannya dalam mengatasi berbagai macam masalah yang ada di rumah sakit, sedangkan pada pertanyaan atasan memberikan pengarahan sebelum melaksanakan tugas didapatkan hasil bahwa sebanyak 48 responden $(84,2 \%)$ menyatakan setuju.

Indikator kedua yaitu kompensasi yang seimbang (equitable compensation). Kompensasi yang seimbang merupakan keseimbangan sistem imbalan yang berikan oleh pihak rumah sakit kepada karyawannya. Hasil penelitian dapat menunjukkan bahwa sebagian besar responden menyatakan gaji yang diterima belum sesuai dengan keinginan sebanyak 29 responden (50,9\%), sedangkan sebanyak 28 responden $(49,1 \%)$ menyatakan bahwa gaji yang terima saat ini sudah sesuai dengan pekerjaan dan tanggungjawab yang diemban. Berdasarkan hasil tersebut dapat disimpulkan bahwa karyawan merasa gaji yang diterima saat ini belum sesuai dengan keinginannya, namun sudah sesuai dengan tanggungjawab yang diemban.

Indikator yang ketiga adalah rasa bangga terhadap intansi (pride). Rasa bangga terhadap instansi tempat kerja dapat diartikan sebagai rasa "memiliki" yang timbul dari dalam diri seorang karyawan atas instansi tempat ia bekerja. Rasa bangga karyawan terhadap rumah sakit juga dapat ditumbuhkan melalui penghargaan dan citra positif yang dibentuk oleh masyarakat terhadap rumah sakit tersebut. Hasil penelitian menujukkan bahwa sebanyak 38 responden $(66,7 \%)$ mempunyai rasa memiliki terhadap rumah sakit tempat ia bekerja , sedangkan sebanyak 24 responden $(42,1 \%)$ menyatakan bahwa ia ingin menghabiskan karirnya di rumah sakit $X$ Surabaya.

Indikator keempat adalah rasa aman terhadap pekerjaan (job security). Rasa aman terhadap pekerjaan dapat diartikan sebagai jaminan yang diberikan oleh rumah sakit kepada karyawannya, seperti jaminan tidak ada pemberhentian karyawan tetap, dan tersedianya jaminan hari tua/pensiun. Hasil penelitian menunjukkan bahw sebanyak 36 responden 
$(63,2 \%)$ merasa bahwa kedudukannya sebagai karyawan di rumah sakit $X$ Surabaya dalam keadaan aman, sedangkan sebanyak 42 responden $(73,7 \%)$ merasa bahwa rumah sakit tidak akan melakukan pemutusan hubungan kerja secara sepihak.

Indikator kelima adalah keselamatan lingkungan kerja (save environment). Keselamatan lingkungan kerja dapat diartikan sebagai upaya yang dilakukan oleh pihak rumah sakit dalam menciptakan lingkungan kerja yang aman sehingga karyawan dapat menjalankan pekerjaannya dengan optimal. Hasil penelitian menunjukkan bahwa sebanyak 43 responden $(75,4 \%)$ menyatakan sarana kesehatan keselamatan kerja yang ada di rumah sakit sudah memenuhi standar, sedangkan sebanyak 43 responden (75,4\%) menyatakan setuju bahwa fasilitas kerja yang ada di rumah sakit membuat mereka aman dalam bekerja.

Indikator keenam adalah kesejahteraan (wellness). Kesejahteraan merupakan usaha yang dilakukan oleh pihak rumah sakit dalam menjamin karyawannya agar tetap bertahan. Upaya mempertahankan karyawan dapat dilakukan melalui penjaminan atas kompensasi, tunjangan, insentif yang diberikan oleh pihak rumah sakit kepada karyawannya sebagai motivasi agar tercapainya produktivitas kerja. Hasil penelitian menunjukkan bahwa sebanyak 48 responden (84,2\%) menyatakan setuju bahwa rumah sakit memberikan tunjangan kepada karyawan sebagai upaya untuk menunjang pemenuhan kebutuhan pokok bagi karyawannya, sedangkan sebanyak 38 responden $(66,7 \%)$ menyatakan bahwa pihak rumah sakit menyediakan jaminan kesehatan bagi karyawannya.

Indikator ketujuh adalah pengembangan karir (career development). Pengembangan karir dapat diartikan sebagai upaya yang diberikan oleh rumah sakit kepada karyawannya berupa pengembangan pengetahuan, keterampilan, maupun perilaku agar mampu meningkatkan kemampuan karyawan. Berdasarkan hasil penelitian diketahui bahwa sebanyak 45 responden $(78,9 \%)$ menyatakan bahwa terdapat kesempatan yang diberikan oleh pihak rumah sakit kepada karyawan untuk mengembangkan karir melalui pelatihan, sedangkan sebanyak 36 responden (63,2\%) menyatakan bahwa sistem kenaikan pangkat dilakukan sesuai dengan latar belakang pendidikan.
Indikator kedepalan adalah penyelesaian konflik (conflict resolution). Penyelesaian konflik merupakan upaya yang dilakukan oleh pihak rumah sakit untuk membantu karyawan dalam menyelesaikan permasalahan yang dihadapi. Hasil penelitian dapat diketahui bahwa sebanyak 44 responden $(77,2 \%)$ menyatakan setuju bahwa jika terjadi konflik dengan rekan kerja maka atasan akan membantu dalam menyelesaikan konflik tersebut, sedangkan mayoritas responden sebanyak 47 orang $(82,5 \%)$ menyatakan setuju bahwa pihak atasan memberikan kesempatan bagi karyawan untuk menerima keluhan apabila terjadi masalah dalam pekerjaan

Indikator kesembilan adalah komunikasi (communication). Komunikasi dapat diartikan sebagai sarana yang diberikan oleh pihak rumah sakit kepada karyawan untuk membangun komunikasi yang efektif antara atasan dengan bawahan. Hasil penelitian menunjukkan bahwa sebanyak 45 responden $(78,9 \%)$ menyatakan bahwa seluruh informasi yang diperlukan oleh karyawan pada tiap unit kerja dikomunikasian dengan baik antara atasan dan bawahan, sedangkan sebanyak 37 responden $(64,9 \%)$ merasa bahwa pertemuan rutin yang dilakukan antara atasan dengan bawahan berjalan dengan baik.

\section{Pengaruh Quality of Work Life terhadap Kepuasan Kerja Karyawan di RSIA X Surabaya}

Analisis pengaruh kualitas kehidupan kerja (quality of work life)terhadap kepuasan kerja karyawan dilakukan dengan membuat tabulasi silang kemudian dilakukan uji statistik untuk mengukur besar pengaruh. Uji statistik yang digunakan untuk menguji besar pengaruh kualitas kehidupan kerja (quality of work life)terhadap kepuasan kerja karyawan adalah regresi linier sederhana. Tabel 1 menunjukkan hasil tabulasi silang antara kualitas kehidupan kerja (quality of work life)dengan kepuasan kerja karyawan.

Berdasarkan Tabel 1 dapat diketahui bahwa responden yang menilai kualitas kehidupan kerja (quality of work life)pada kategori cukup dengan kepuasan kerja pada kategori sedang diperoleh hasil sebanyak 32 responden $(80,0 \%)$, sedangkan responden yang menilai kualitas kehidupan kerja (quality of work life)pada kategori baik dengan kepuasan kerja pada kategori tinggi diperoleh hasil sebanyak 9 orang $(52,90 \%)$.

Tabel 1. Tabulasi Silang antara Quality of Work Life dengan Kepuasan Kerja Karyawan di RSIA X Surabaya

\begin{tabular}{lcccccc}
\hline \multirow{2}{*}{ Quality of Work Life } & \multicolumn{4}{c}{ Kepuasan Kerja } & \multicolumn{2}{c}{ Total } \\
\cline { 2 - 6 } & \multicolumn{2}{c}{ Sedang } & \multicolumn{2}{c}{ Tinggi } & \multicolumn{2}{c}{$\%$} \\
\cline { 2 - 7 } & $\mathbf{n}$ & $\%$ & $\mathbf{n}$ & $\%$ & $\mathbf{N}$ & $100,00 \%$ \\
\hline Cukup & 32 & $80,00 \%$ & 8 & $20,00 \%$ & 40 & $100,00 \%$ \\
\hline Baik & 8 & $47,10 \%$ & 9 & $52,90 \%$ & 17 & $100,00 \%$ \\
\hline Total & 40 & $70,18 \%$ & 17 & $29,28 \%$ & 57 & 100 \\
\hline
\end{tabular}

Berdasarkan hasil tabulasi silang tersebut dapat diketahui kepuasan kerja karyawan meningkat apabila diimbangi dengan semakin baiknya kualitas kehidupan kerja (quality of work life). Hal tersebut sejalan dengan penelitian yang dilakukan oleh (Ace, 2017) yang menyebutkan bahwa kepuasan kerja akan cenderung meningkat seiring dengan baiknya kualitas kehidupan kerja (quality of work life)yang diciptakan oleh rumah sakit. Selanjutnya, dilakukan uji statistik untuk mengetahui pengaruh kualitas kehidupan kerja (quality of work life)terhadap kepuasan kerja karyawan. Berikut adalah hasil uji regresi linier 
sederhana untuk menguji pengaruh kualitaskehidupan kerja (quality of work life)terhadap kepuasan kerja karyawan:

Hasil uji regresi linier sederhana untuk menganalisis pengaruh kualitas kehidupan kerja (quality of work life)terhadap kepuasan kerja menunjukkan nilai signifikansi ( $p$-value) sebesar 0,024 dan lebih kecil dari a yaitu 0,05. Maka dapat disimpulkan bahwa terdapat pengaruhkualitas kehidupan kerja (quality of work life)terhadap kepuasan kerja. Adanya pengaruh positif kualitas kehidupan kerja (quality of work life)terhadap kepuasan kerja didukung dengan penelitian yang dilakukan oleh (Setiyadi and Wartini, 2016) yang menunjukkan bahwa kualitas kehidupan kerja (quality of work life) memiliki pengaruh positif terhadap kepuasan kerja. Penelitian yang dilakukan oleh (Winasih, Nursalam and K, 2015) didapatkan hasil bahwa kualitas kehidupan kerja (quality of work life)memiliki pengaruh yang signifikan terhadap kepuasan kerja perawat di RSUD Dr. Soetomo Surabaya. Hal tersebut sesuai dengan yang diungkapkan oleh (Cascio, 2015) yang menyatakan bahwa kualitas kehidupan kerja (quality of work life)dapat menumbuhkan keinginan karyawan untuk tetap bertahan dalam sebuah organisasi.

Hal tersebut didasarkan pada konsep bahwa kepuasan kerja karyawan dapat dilihat dari dua aspek. Pertama, perasaan memiliki organisasi dan kedua adalah tanggungjawab yang dimiliki oleh karyawan untuk menciptakan produktivitas kerja. Perasaan yang kuat terhadap kedua aspek tersebut merupakan wujud dari kualitas kehidupan kerja (quality of work life)yang semakin baik

Tabel 2.Hasil Uji Regresi Pengaruh Quality of Work Life terhadap Kepuasan Kerja Karyawan di RSIA X Surabaya

\begin{tabular}{|c|c|c|c|c|c|c|c|c|c|}
\hline \multirow{2}{*}{\multicolumn{2}{|c|}{ Model }} & & \multicolumn{2}{|c|}{$\begin{array}{l}\text { Unstandardized } \\
\text { Coefficients }\end{array}$} & \multirow{2}{*}{$\begin{array}{c}\begin{array}{c}\text { Standardized } \\
\text { Coefficients }\end{array} \\
\text { Beta }\end{array}$} & \multirow{2}{*}{$\mathbf{T}$} & \multirow{2}{*}{ Sig } & \multicolumn{2}{|c|}{ Collinearity Statistics } \\
\hline & & & B & $\begin{array}{l}\text { Std. } \\
\text { Error }\end{array}$ & & & & Tolerance & VIF \\
\hline \multirow[t]{2}{*}{1} & (Constant) & & 1,571 & ,157 & & 9,982 & 0,000 & & \\
\hline & $\begin{array}{l}\text { Quality } \\
\text { Work Life }\end{array}$ & of & , 157 & ,068 & 299 & 2,328 & 0,024 & 1,000 & 1,000 \\
\hline
\end{tabular}

Komitmen dari pihak manajemen maupun karyawan untuk meningkatkan kualitas kehidupan kerja (quality of work life)dapat menciptakan sikap positif yang diberikan karyawan terhadap organisasinya. Sikap positif yang timbul dari diri seorang karyawan akibat dari kualitas kehidupan kerja (quality of work life) yang baik antara lain adalah timbulnya motivasi dan semangat yang tinggi terhadap pekerjaannya, meningkatnya kesejahteraan karyawan, menciptakan suasana dan hubungan kerja yang baik antara pimpinan dan karyawan, meningkatkan loyalitas karyawan terhadap perusahaan. Apabila karyawan merasa puas dengan pekerjaannya maka motivasi yang dimiliki juga akan semakin tinggi sehingga pada akhirnya karyawan akan cenderung untuk tetap bertahan dalam sebuah organisasi (Rahmat Putra, 2017). Hal tersebut merupakan salah satu bentuk kepuasan yang dirasakan oleh karyawan terhadap pekerjaannya. Kualitas kehidupan kerja (quality of work life)yang selalu diperhatikan dalam jangka panjang mampu menciptakan kepuasan kerja yang dirasakan oleh karyawan terhadap pekerjaan yang dimilikinya.

Berdasarkan penelitian yang dilakukan oleh (Jaiswal, Mahila and Varanasi, 2014) dapat diketahui bahwa dengan menerapkan kualitas kehidupan kerja (quality of work life)yang baik maka dapat memiliki berbagai manfaat antara lain adalah mampu meningkatkan kepuasan kerja karyawan, mampu meningkatkan kesehatan karyawan baik secara fisik maupun psikologis sehingga dapat menciptakan suasana yang positif, menambah produktivitas karyawan, dan mampu membangun citra sebagai organisasi yang memiliki karyawan dengan motivasi yang tinggi dalam bekerja. Adapun teknik yang dapat dilakukan oleh sebuah organisasi untuk meningkatkan kualitas kehidupan kerja (quality of work life)yaitu dengan job redesign, pengembangan karir, jadwal kerja yang fleksibel,

dan jaminan keamanan terhadap pekerjaan. Apabila sebuah rumah sakit mampu meningkatkan kualitas kehidupan kerja (quality of work life) maka dapat berdampak terhadap kepuasan pasien. Hal tersebut dikarenakan pasien sebagai penerima pelayanan primer akan merasakan dampak semakin baiknya kinerja karyawan. Hal tersebut didasarkan pada

\section{SIMPULAN}

Berdasarkan penelitian yang telah dilakukan dapat disimpulkan bahwa terdapat pengaruh kualitas kehidupan kerja (quality of work life)terhadap kepuasan kerja karyawan RSIA X Surabaya. Hal tersebut menunjukkan bahwa kepuasan kerja karyawan akan meningkat seiring dengan baiknya kualitas kehidupan kerja (quality of work life)yang dirasakan oleh karyawan, dan begitupula sebaliknya.

Kepuasan kerja karyawan RSIA X Surabaya berada pada kategori sedang sehingga kedepannya dapat ditingkatkan dengan memperhatikan keseluruhan aspek kualitas kehidupan kerja (quality of work life). Hal tersebut dikarenakan kualitas kehidupan kerja (quality of work life)merupakan salah satu aspek penting yang dapat mempengaruhi kepuasan kerja karyawan. Apabila sebuah rumah sakit mampu menciptakan kualitas kehidupan kerja (quality of work life)yang baik maka karyawan akan merasa diperhatikan oleh pihak rumah sakit sehingga diharapkan karyawan dapat bertahan dalam pekerjaan yang ditekuninya dan mampu memberikan kinerja yang optimal bagi pihak rumah sakit. 


\section{DAFTAR PUSTAKA}

Ace, A. (2017) 'Pengaruh Kualitas Kehidupan Kerja dan Partisipasi terhadap Kepuasan Kerja Perawat RSUD Bangkinang', Jurnal Online Mahasiswa FISIP, 4(2), pp. 1-8. Available at: https://media.neliti.com/media/publications/1 15484-ID-pengaruh-kualitas-kehidupankerja-dan-pa.pdf.

Budi Santoso, A. (2012) Analisis Hubungan Antara Perbedaan Karakteristik Biografis Individu Dengan Tingkat Kepuasan Kerja Pegawai di PT Bank Jabar Banten Bandung. Bandung. Available

at: https://repository.widyatama.ac.id/xmlui/bitstr eam/handle/123456789/2805/ANTON.pdf?s equence $=2$.

Cascio, W. (2016) Managing Human Resources: Productivity, Quality of Work Life, Profits. Edited by 10. New York: Mc Graw Hill Education.

Haedar, Saharuddin and H, H. (2015) 'Pengaruh Lingkungan Kerja dan Masa Kerja Terhadap Kepuasan Karyawan pada PT. Hadji Kalla Palopo', Jurnal Manajemen, 2(1), pp. 10-22. Available

at: http://journal.stiem.ac.id/index.php/jurman/art icle/view/158/134.

Jaiswal, A., Mahila, A. and Varanasi (2014) 'Quality Of Work Life', Journal of Business Management \& Social Science Research, 3(2), pp. 83-87. Available at: http://citeseerx.ist.psu.edu/viewdoc/downloa d?doi=10.1.1.428.8341\&rep=rep1\&type=pdf.

Rahmat Putra, M. F. (2017b) 'Pengaruh Kepuasan Kerja dan Komitmen Organisasi Terhadap Intention to Leave di Rumah Sakit Pura Raharja Surabaya', Jurnal Administrasi Kesehatan Indonesia, 5(2), pp. 99-104. doi: 10.20473/jaki.v5i2.2017.99-104.

Rivai, V. et al. (2014) Manajemen Sumber Daya Manusia untuk Perusahaan dari Teori ke Praktik. 6th edn. Jakarta: PT RajaGrafindo Persada.

Robbins, S. P. and Judge, T. A. (2013) Perilaku Organisasi Organizational Behavior. 16th edn. United States: Pearson.

Setiyadi, Y. W. and Wartini, S. (2016a) 'Pengaruh Kualitas Kehidupan Kerja terhadap Kinerja Karyawan dengan Kepuasan Kerja sebagai Variabel Intervening', Management Analysis Journal, 5(4), pp. 315-324.

Sholeha, M., Kristanti, M. and Jokom, R. (2015) 'Kepuasan Kerja Karyawan Gogo Café Di Hotel Oval Surabaya', Jurnal Hospitality dan Manajemen Jasa, 3(1), pp. 396-409. Available at: https://media.neliti.com/media/publications/8 1350-ID-kepuasan-kerja-karyawan-gogocafe-di-hot.pdf.

Suryaratri, R. D. and Rizanati, M. (2017) 'Kepuasan Kerja Ditinjau Dari Motivasi Kerja Pada Karyawan Kontrak di PT.X', Jurnal Penelitian dan Pengukuran Psikologi, 6(2), pp. 88-93. doi: https://doi.org/10.21009/JPPP.062.05.

Winasih, R., Nursalam and Dian, N. (2015) 'Budaya organisasi dan Quality of Nursing Work Life Terhadap Kinerja dan Kepuasan Kerja Perawat Di RSUD Dr. Soetomo Surabaya', Ners, 10(2), pp. 332-342. Available at: https://e-

journal.unair.ac.id/JNERS/article/view/21/110 6.

Wursanto, I. (2010) Dasar-Dasar Ilmu Organisasi. Yogyakarta: Andi Publisher.

Zein, D. R., Setyaningrum, R. and Marlinae, L. (2016b) 'Pengaruh Usia, Pendidikan Dan Jaminan Sosial Terhadap Kepuasan Kerja Karyawan Bagian Operator di PT. Cakrawala Putra Bersama', Jurnal Publikasi Kesehatan Masyarakat Indonesia, 3(2), pp. 38-44. 